\title{
Effect of Bacterial-algal Biostimulant on the Yield and Internal Quality of Lettuce (Lactuca sativa L.) Produced for Spring and Summer Crop
}

\author{
Tomáš KOPTA ${ }^{1 *}$, Marcela PAVLÍKOVÁ², Agnieszka SĘKARA³ \\ Robert POKLUDA ${ }^{1}$, Blahoslav MARŠÁLEK ${ }^{4}$
}

\author{
${ }^{1}$ Mendel University in Brno, Faculty of Horticulture, Department of Vegetable Growing and Floriculture, Valtická 337, 69144 Lednice, \\ CzechRepublic; tomas.kopta@mendelu.cz (*correspondingauthor);robert.pokluda@mendelu.cz \\ ${ }^{2}$ Brno University of Technology, Faculty of Civil Engineering, Institute of Chemistry, Veverí 331/95, 60200 Brno, \\ Czech Republic;pavlikovamarcel@gmail.com \\ ${ }^{3}$ University of Agriculture in Krakow, Faculty of Biotechnology and Horticulture, Department of Vegetable and Medicinal Plants, \\ 29 Listopada 54, Kraków, Poland; a.sekara@ur.krakow.pl \\ ${ }^{4}$ Brno University of Technology, Faculty of Chemistry, Purkyñova 118, 61200 Brno, Czech Republic; blahoslav.marsalek@gmail.com
}

\begin{abstract}
Plant biostimulants can enhance crop nutrition status, stress tolerance, yield and quality in environment-friendly manner. The aim of this study was to determine the effect of an algae and bacteria preparations on the yield and nutritional parameters of leaf and romaine lettuce cultivated for spring and summer crop. The application of a combined biostimulant consisting of plant growth-promoting bacteria (Bacillus licheniformis, Bacillus megatherium, Azotobacter sp., Azospirillum sp., and Herbaspirillum sp.) and fresh water algae (Chlorella vulgaris) was done by watering the lettuce every 14 days, and a determination of the fresh weight, total antioxidant capacity, and total carotenoids content was performed. The result revealed that the application of bacterial-algal preparation significantly affected the plant weight of both romaine and leaf lettuce in spring and summer seasons. The highest increase in the weight of romaine lettuce reached $18.9 \%$ in the spring crop, while in the case of leaf lettuce, biostimulant treatment led to a $22.7 \%$ higher weight in the summer crop. Total antioxidant capacity and total carotenoids content showed increased values in the summer crop of romaine lettuce, while for the leaf lettuce there were no differences between treatments. Therefore, the positive effect of bacterial-algal treatment on lettuce yield, total antioxidant capacity and total carotenoids confirm that it could be applied for improving romaine lettuce yield quality and quantity, especially in stress, summer conditions.
\end{abstract}

Keywords: sustainable agriculture; microalgae; PGPB; total antioxidant capacity; total carotenoids

\section{Introduction}

Plant biostimulants, described as any substance or microorganism applied to plants with the aim of enhancing nutrition efficiency, abiotic stress tolerance, and/or crop quality traits (du Jardin, 2015), have a steadily growing market, according to market analysis reports (Marketsandmarkets.com, 2014). Microorganisms and their metabolites that are capable of enhancing soil fertility, crop growth, and/or yield could provide an alternative to agricultural chemicals (Von Bennewitz and Hlušek, 2006).

Freshwater microalgae are known to produce a broad spectrum of biologically active compounds such as phytohormones, enzymes, antibiotics, and vitamins (Tsavkelova et al., 2006; Bertoldi et al., 2008). In addition, microalgae extracellular enzymes can transform nutrients to more bioavailable forms that improve nutrient availability for both soil microflora and plants. Examples of this are the phytohormones produced by freshwater algae, which can directly affect the physiological processes, morphogenesis, reproduction, rhizogenesis, and growth of cultivated plants (Tarakhovskaya et al., 2007).

Together with algal antimicrobial compounds, plant growth-promoting bacteria (PGPB) has been shown to protect plants from phytopathogenic fungi and bacteria. An important property of PGPB is its production of biopolymers, which improve the water-retention capacity of rhizosphere and are reported to be the protection mechanism of PGPB against drought stress (Noaman et al., 2004). Bacteria interactions with plants can influence the supply of nutrients, increase nutrient use efficiency, induce disease resistance, enhance abiotic stress tolerance, and modulate morphogenesis through plant growth regulators (Ahmad et al., 2008). 
616

Herbaspirillum sp. produces auxins (Yin et al., 2015), which support the root system of plants (Takahashi, 2013), and extracellular phosphatases (Pfeiffer, 1996), which exposes phosphorus to plants (Lee, 1988); Chlorella vulgaris helps to start initial bacterial growth (Cole, 1982; Watanabe et al., 2005); Azotobacter sp. produces extracellular biopolymers (Remminghorst and Rehm, 2006), which are necessary for aquaretence capacity cover (Or et al., 2007; Redmile-Gordon et al., 2015); while Azotobacter sp. and Azospirillum sp. fix nitrogen and produce siderophores (Steenhoudt and Vanderleyden, 2000; Jiménez et al., 2011).

There is increasing interest in enhancing the nutritional quality of fresh produce. Leafy vegetables, mainly different varieties of lettuce, are commonly cultivated and consumed all over a world. The optimal temperature range for lettuce development is $15-20^{\circ} \mathrm{C}$, growth inhibition emerges under high temperatures in summer (Han et al., 2016). Summer production offered the lower glucose and fructose as well as higher nitrate content in lettuce as compared to spring cultivation (Fallovo et al., 2009). There was also noted lower water use efficiency due to the high radiation and temperature that may have reduced the rate of photosynthesis and increased respiratory losses. The sensory properties of lettuce also fluctuated widely throughout the growing season, at higher temperatures and bitterness increased generally in relation to higher phenolic content (Bunning et al., 2010). The effect of growing season on leafy lettuce yield and quality was more pronounced than the effect of nutrient solution composition (Fallovo et al., 2009). Additionally the proper mineral nutrition and chemical protection of lettuce is difficult because of short vegetation period and risk of high level of nitrate concentration and pesticide residues (Skovgaard et al., 2017).

Leafy vegetables are the most often eaten raw so they need specific attention with respect to safety, guaranteed, inter alia, by organic production technologies including application of beneficial microorganisms. A significant contribution of Azotobacter and vermicompost on lettuce yield was reported by Chatterjee (2015). According to Muymas et al. (2015), no significant differences in fresh weight and dry weight were observed between the control and lettuces treated with Bacillus licheniformis. The leaf number, width, and length of treated lettuces were slightly lower than the control plants in the first and third crop seasons. These results indicate that the application of Bacillus licheniformis alone did not promote the growth of lettuce in any crop season. Colla et al. (2015) stressed that the application of the biostimulant tablet containing Glomus intraradices and Trichoderma atroviride can promote transplant establishment and vegetable crop productivity in a sustainable way. There is already some evidence of increases in the total phenolics and flavonoids content and antioxidant activity in spinach after the application of algae extracts (Fan et al., 2011). Lettuce grown in stress conditions, treated with a microbial-based biostimulant containing Rhizophagus intraradices and Trichoderma atroviride, was characterised by higher chlorophyll content and photochemical activity of PSII, and a better nutritional status in the leaf tissue (Rouphael et al.,
2017). According to mentioned references rhizosphere bacteria can have negative, neutral, or positive effects on plant growth. Most recommendations for the soil application of beneficial microorganisms in vegetable production do not take into account environmental conditions. Therefore, different temperature, water and solar radiation conditions may be good treatments variable determine possible interactions of environmental conditions and beneficial microorganisms application.

We hypothesised that the combination of freshwater algae and plant growth-promoting bacteria affect yield and nutritional value of leaf lettuce and romaine lettuce and the influence should be different depending on the term of cultivation. We assumed that beneficial microorganisms can promote lettuce growth especially in summer season when high temperature can be stressful for plants.

\section{Materials and Methods}

\section{Biologicalmaterial}

Leaf lettuce (Lactuca sativa var. crispa L.) cv. 'Santoro' and romaine lettuce (Lactuca sativa L. var. longifolia Lam.) cv. 'Quintus' were grown as spring and summer crops in a commercial field on medium-heavy loam soil ( $\mathrm{N}$ - min. 5.6 $\mathrm{mg} \cdot \mathrm{kg}^{-1}$ ) in a warm, slightly dry climate region (GPS $49^{\circ} 9^{\prime} 55^{\prime \prime} \mathrm{N}, 16^{\circ} 38^{\prime} 14^{\prime \prime} \mathrm{E}$ ) in the Czech Republic (average annual temperature $8-9^{\circ} \mathrm{C}$, average rainfall $500-600 \mathrm{~mm}$ ). Crops were grown using standard commercial management practices. The spring 4-week-old seedlings of both varieties were planted on April 25, with spacing of $0.3 \times 0.25 \mathrm{~m}$. The harvest was realised on June 6 (leaf lettuce) and June 16 (romaine lettuce). The summer 3-week-old seedlings of both types were planted on June 19 , with of spacing $0.3 \times$ $0.25 \mathrm{~m}$. Fertilisation, included NPK (7-20-28) totally with $83 \mathrm{~kg} \cdot \mathrm{ha}^{-1}$ of N, was done 2 weeks before planting. Irrigation was applied by overhead sprinklers for $3 \mathrm{~h}$, three times per week $(10 \mathrm{~mm}$ each), started immediately after planting. The local meteorological station recorded a mean temperature and mean maximum temperature which is presented in Table 1. Mean temperature was within the optimal limit recommended for lettuce by Han et al. (2016) in spring season with the exception of $8^{\text {th }}$ week of growing, but exceeded this limit in 5-8 ${ }^{\text {th }}$ week in summer season. Maximum temperature was above the optimal level during whole summer growing period.

\section{Treatment and experimental design}

Plant growth-promoting substances protected as utility model No. 29940 by the Czech Industrial Property Office, was used as the treatment. This product contains a mixture of the following bacterial and algal cultures: Bacillus licheniformis strain RAWAT 7C, Bacillus megatherium strain RAWAT 2A, Azotobacter sp., strain RAWAT 15C, Azospirillum, strain RAWAT 21A, Azotobacter strain RAWAT 13B, Herbaspirillum sp. strain RAWAT 31D and strain 35, Chlorella vulgaris strain Marsalek 85, at a concentration of $10^{7} \mathrm{cfu} \cdot \mathrm{g}^{-1}$. The composition follows the biologically active compounds produced by particular microorganisms. Bacterial-algal treatment (BA) was applied by watering in 0.41 of substance per plant every 14 days, and a total of four applications were performed. In the control treatment, only fresh water was applied. 
Table 1. Mean and maximum temperatures $\left({ }^{\circ} \mathrm{C}\right)$ during spring and summer season of lettuce cultivation in the field

\begin{tabular}{cccccc}
\hline & Spring growing season & \multicolumn{3}{c}{ Summer growing season } \\
\hline Calendar week & Mean temp. & Max temp. & Calendar week & Mean temp. & Max temp. \\
\hline 21-27 April & 14.8 & 19.1 & $16-22$ June & 17.9 & 22.8 \\
28 April-4 May & 13.5 & 19.4 & $23-29$ June & 18.7 & 24.9 \\
5-11 May & 13.5 & 18.7 & 30 June-6 July & 19.4 & 24.7 \\
12-18 May & 10.7 & 14.1 & $7-13$ July & 20.5 & 26.0 \\
19-25 May & 20.0 & 25.5 & $214-20$ July & 24.1 & 30.7 \\
26 May-1 June & 15.2 & 20.0 & 28 July-3 August & 22.1 & 2.5 \\
2-8 June & 18.3 & 23.8 & $4-10$ August & 21.8 & 27.1 \\
9-15 June & 22.3 & 27.8 & - & - & 26.8 \\
16-22 June & 17.9 & 22.8 & Mean & 20.88 & - \\
Mean & 16.24 & 21.24 & & 26.44 \\
\hline
\end{tabular}

The experiment evaluating the effect of BA treatment was arranged in a split-plot design containing 350 plants in each treatment, which consisted of four replicates. For the determination of lettuce weight, ten plants per replicate were selected according to quality standards for commercial production (UNECE Standard FFV-22, 2012).

\section{Evaluation of yield, nutrition's and statistical analysis}

The harvest was realised on August 4 (leaf lettuce) and August 8 (romaine lettuce) according to the market quality standards (UNECE Standard FFV-22, 2012). Whole rosettes were harvested by hand, the outer leaves with the symptoms of damage or deterioration were removed, plants were weighted to estimate the marketable yield. For nutrient analysis, three plants per a replicate were collected at harvest time. A $20 \mathrm{~g}$ sections of each head of lettuce, including inner and outer leaves were homogenised and used for subsequent analyses. Antioxidant activity was determined using the modified DPPH (2.2-diphenyl-1picrylhydrazyl) assay (Brand-Williams et al., 1995), with absorbance at $515 \mathrm{~nm}$. The results were expressed as $\mathrm{mM}$ Trolox equivalents (TE) per $1000 \mathrm{~g}$ of fresh weight (FW). The total carotenoids were determined by spectrometry at a wavelength of $440 \mathrm{~nm}$, using a Jenway 6100 (GB) spectrophotometer and expressed as $\mu \mathrm{g} \cdot \mathrm{g}^{-1}$ of FW, according to Holm (1954). Data were compared using analysis of variance (ANOVA) at a significance level of $p<0.05$. Data were analysed using Statistica 12 (StatSoft).

\section{Results and Discussion}

\section{The effect of bacterial-algal preparation on lettuce yield}

The application of the BA preparation significantly affected the romaine and leaf lettuce weight (Fig. 1). Average romaine lettuce weight varied between 526-690 g, which is higher than the range of 243-356 g reported by Hoque et al. (2010) for romaine lettuce under different $\mathrm{N}$ fertilisation, and lower than that of Thorp et al. (2016), who obtained an average lettuce weight of $715-998 \mathrm{~g}$. Average weight of leaf lettuce varied between 268 and $415 \mathrm{~g}$ which is in line with the results of Esringu et al. (2015), who obtained an average leaf lettuce weight of around $346 \mathrm{~g}$. The application of BA led to a significantly higher lettuce weight compared to the control; the increase of lettuce weight was $18.9 \%$ and $12.9 \%$ for roman lettuce and $16.5 \%$ and $22.7 \%$ for leaf lettuce, in the spring and summer crops, respectively. The lower yield harvested in summer season indicated the temperature stress which was significantly moderated by BA application in both lettuce varieties. Numerous studies have indicated that the application of combined microbial preparations (polyvalent inoculum) can sometimes give better results than untreated control (Jarak et al., 2006), which is in line with our findings. The combined preparation used in this trial increased the lettuce weight for both varieties. The results of our experiment show that the combination of selected bacteria and fresh water algae can be promising way to positively influence crop yield especially in stress conditions.

The effect of bacterial-algal preparation on lettuce total antioxidant capacity

Lettuce may serve as potential dietary sources of natural phenolic antioxidants (Liu et al., 2007). The TAC for the spring and summer crop was generally higher in leaf lettuce as compared to romaine. In the spring crop of romaine lettuce, the TAC for BA treatment was $23 \%$ lower but in the summer crop 2.5 times higher as compared to the control (Fig. 2). For leaf lettuce differences were not significant. TAC values noted for both lettuce varieties were higher than those of Reyes et al. (2007). Being a cool-season crop, lettuce is particularly vulnerable to heat stress. According the meteorological data (see $M \& M$ ), it is obvious that the summer crop was grown under a higher temperature, compared to the spring crop. Certain plant stress incidence could be assumed. Almeselmani et al. (2006) and Babu et al. (2008) stated that tolerance to high temperature stress in crop plants has been associated with an increase in antioxidative capacity. In the case of romaine lettuce, low antioxidant capacity in the summer crop was significantly improved by BA treatment, leading to increase the tolerance against heat stress and better yielding as compared to the control treatment in this season of cultivation. According to Liu et al. (2007) leaf lettuce possessed the highest TPC and highest DPPH scavenging ability, followed by romaine, butterhead and Batavia. In the conditions of present experiment, the TAC of leaf lettuce remain high and stable independently on season and treatment. For this variety not TAC but the other mechanisms could be involved in positive reaction on BA treatment. 

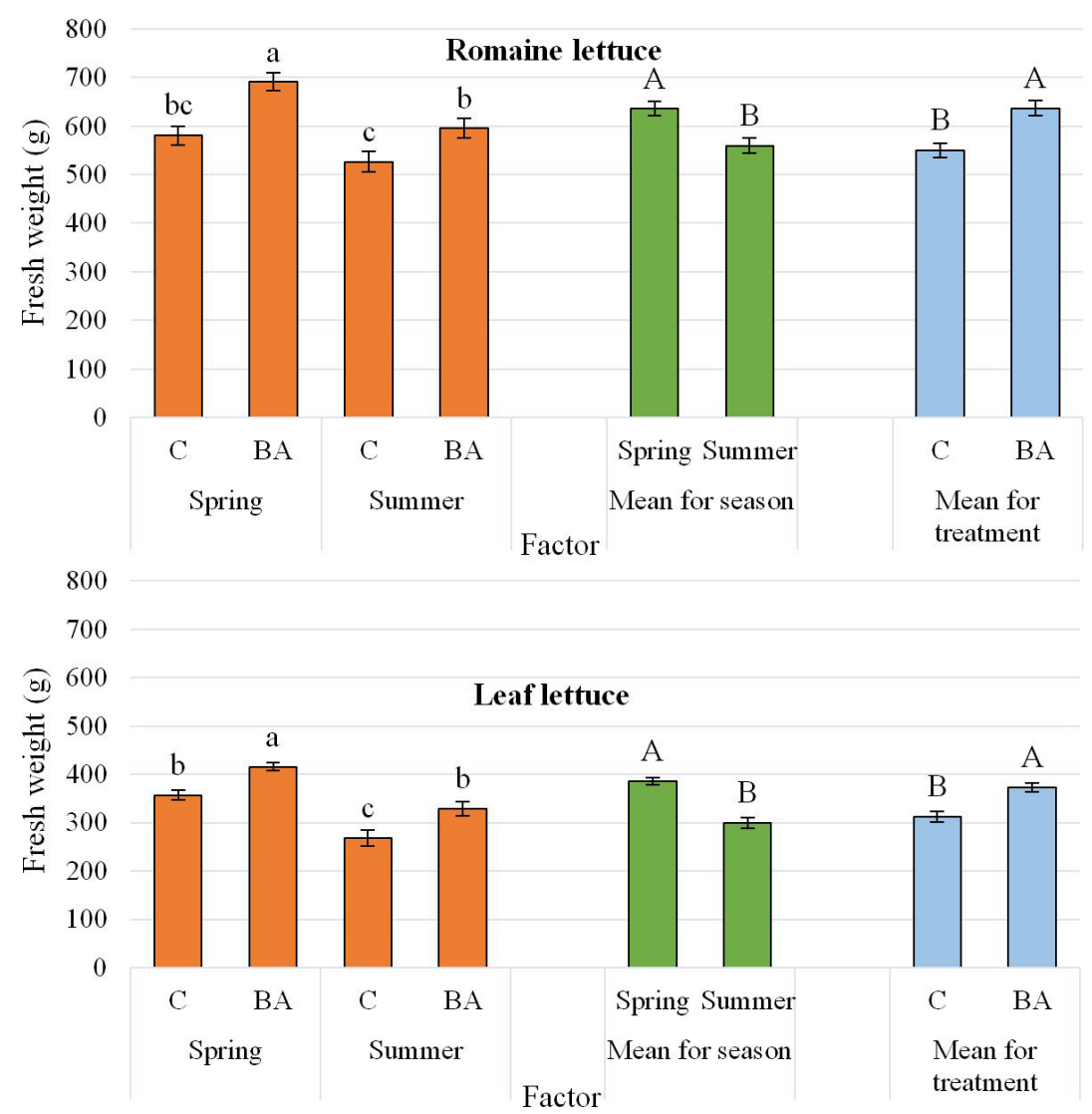

Fig. 1. Effect of bacterial-algal application, term of cultivation and their interactions on the fresh weight $(\mathrm{g})$ of two lettuce varieties. Note: different lowercase letters represent significant $(p<0.05)$ differences in the interaction effects, while capital letters - in the main effects as determined by a two-way ANOVA and Fisher's LSD test, bars represent standard errors ( \pm SE). $\mathrm{BA}$ - bacterial-algal preparation, $\mathrm{C}$ - control

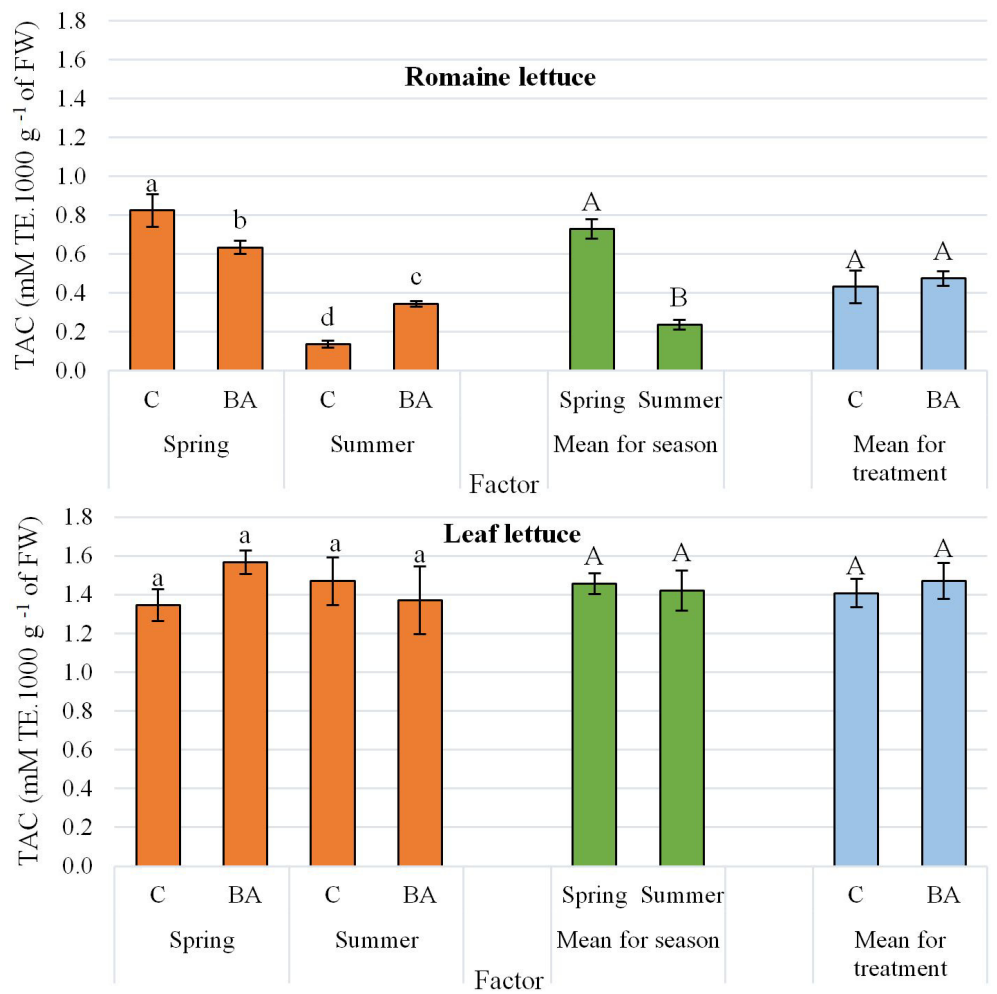

Fig. 2. Effect of bacterial-algal application, term of cultivation and their interactions on the total antioxidant activity (mM Trolox $\left.1000 \mathrm{~g}^{-1} \mathrm{FW}\right)$ of two lettuce varieties. Note: different lowercase letters represent significant $(\mathrm{p}<0.05)$ differences in the interaction effects, while capital letters - in the main effects as determined by a two-way ANOVA and Fisher's LSD test, bars represent standard errors $( \pm$ SE). BA - bacterial-algal preparation, $\mathrm{C}$ - control 

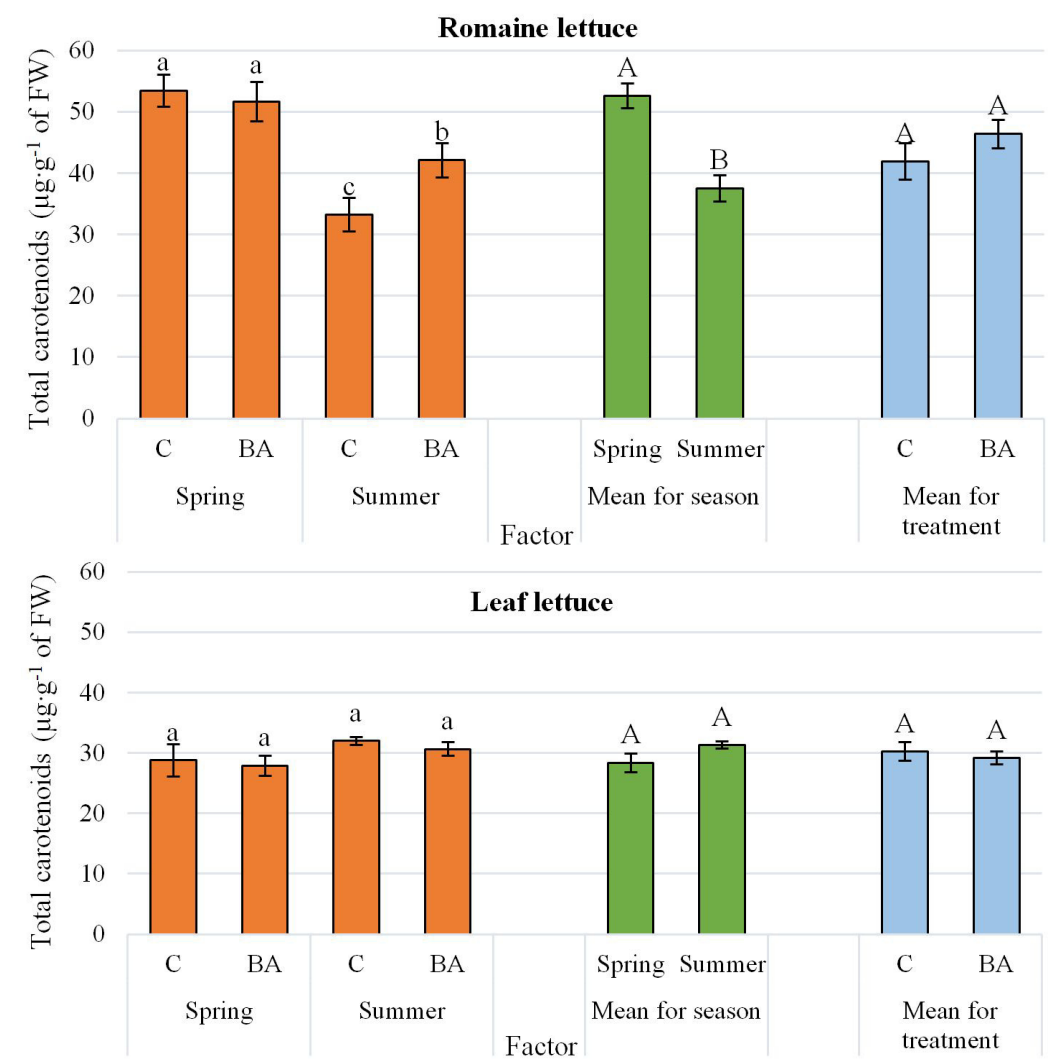

Fig. 3. Effect of bacterial-algal application, term of cultivation and their interactions on the total carotenoids content $\left(\mu \mathrm{g} \cdot \mathrm{g}^{-1} \mathrm{FW}\right)$ of two lettuce varieties. Note: different lowercase letters represent significant $(p<0.05)$ differences in the interaction effects, while capital letters - in the main effects as determined by a two-way ANOVA and Fisher's LSD test, bars represent standard errors ( \pm SE). BA - bacterial-algal preparation, $C$ - control

\section{The effect of bacterial-algal preparation on lettuce total carotenoids content}

Total carotenoids content varied between 33.21 and $53.47 \mu \mathrm{g} \cdot \mathrm{g}^{-1} \mathrm{FW}$ for romaine lettuce but significant differences between treatments were observed only during summer time of cultivation (Fig. 3), BA treatment led to a significant increase of total carotenoids, of $26.7 \%$. These values are lower than those reported by Saini et al. (2016), where the average content of total carotenoids in green romaine lettuce reached $88.4 \mu \mathrm{g} \cdot \mathrm{g}^{-1} \mathrm{FW}$. The results obtained for leaf lettuce are slightly below the level 37.75 $\mu \mathrm{g} \cdot \mathrm{g}^{-1} \mathrm{FW}$ reported by Amanda et al. (2009), where the summer crop grown under a plastic tunnel reached a generally higher total carotenoids content compared to the spring crop, despite their being no difference between the treatments. Romaine and leaf lettuce head structure determine the penetration of the sunlight and therefore accelerating the synthesis of light-dependent metabolites. This conclusion can be supported by the results of Mou and Ryder (2004) on relationship between the nutritional value and the head structure of lettuce. Subsequent investigations of Mou (2005) on genetic variability in carotenoid contents of 52 genotypes of lettuce allow for recognise leaf and romaine lettuce as the best carotenoids source, followed by butterhead and crisphead varieties. Additionally, our results let to conclude that summer high temperatures and insolation seem to promote decreasing of total carotenoids content in romaine but not leaf lettuce.

\section{Conclusions}

The application of bacterial-algal preparation of lettuce can be an environmentally friendly manner of improving the yield and biological quality, especially in stress conditions of summer cultivation. Microbial inoculation applied to alleviate stresses in plants could be more costeffective and available in a shorter time, compared to the development of a stress tolerant crop genotypes. There is a need for further studies with more vegetable species included as well as different production periods to find out which factors (climatic, agronomic, etc.) enhance the BA effect on plant nutritional quality.

\section{Acknowledgements}

This work was supported by a project of the Technology Agency of the Czech Republic - Biological additives of irrigation water for quality enhancement of food crop (TA02020544).

\section{References}

Ahmad F, Ahmad I, Aqil F, Khan MS, Hayat S (2008). Diversity and Potential of Nonsymbiotic Diazotrophic Bacteria in Promoting Plant Growth. In: Ahmad I, Pichtel J, Hayat S (Eds). Plant-Bacteria Interactions: Strategies and Techniques to Promote Plant Growth. Weinheim, Germany, Wileypp 81-109. 
620

Almeselmani M, Deshmukh PS, Sairam RK, Kushwaha SR, Singh TP (2006). Protective role of antioxidant enzymes under high temperature stress. Plant Science 171:382-388.

Amanda A, Ferrante A, Valagussa M, Piaggesi A (2009). Effect of biostimulants on quality of baby leaf lettuce grown under plastic tunnel. Acta Horticulturae 807:407 412.

Babu NR, Devraj VR (2008). High temperature and salt stress response in French bean (Phaseolus vulgaris). Australian Journal of Crop Science 2:40-48

Bertoldi FC, Sant'Anna E, Oliveira JLB (2008). Review: Microalgae biotechnology. Boletim Centro de Pesquisa de Processamento de Alimentos A26(1):9-20.

Brand-Williams W, Cuvelier ME, Berset C (1995). Use of a free radical method to evaluate antioxidant activity. Food Science and Technology 28:25-30.

Bunning ML, Kendall PA, Stone MB, Stonaker FH, Stushnoff C (2010). Effects of seasonal variation on sensory properties and total phenolic content of 5 lettuce cultivars. Journal of Food Science 75(3):S156-S161.

Chatterjee R (2015). Influence of nutrient sources on growth, yield and economics of organic lettuce production under foothills of eastern Himalayan region. Emirates Journal of Food and Agriculture 27(5):460-462.

ColeJJ (1982). Interactions between bacteria and algae in aquatic ecosystems. Annual Review of Ecology, Evolution, and Systematics 13:291-314

Colla G, Rouphael Y, Di Mattia E, El-Nakhel C, Cardarelli M (2015). Coinoculation of Glomus intraradices and Trichoderma atroviride acts as a biostimulant to promote growth, yield and nutrient uptake of vegetable crops. Journal of the Science of Food and Agriculture 95:1706-1715.

Du Jardin P (2015). Plant biostimulants: Definition, concept, main categories and regulation. Scientia Horticulturae 196:3-14.

Esringu A, Ekinci M, Turan M, Usta S, Dursun A, Ercisli S, Yildirim E (2015). Selenium supplementation affects the growth, yield and selenium accumulation in lettuce (Lactuca sativa $\mathrm{L}$.). Comptes Rendus deL'Academie Bulgare des Sciences 68(6):801-810.

Fallovo C, Rouphael Y, Cardarelli M, Rea E, Battistelli A, Colla G (2009). Yield and quality of leafy lettuce in response to nutrient solution composition and growing season. Journal of Food, Agriculture and Environment 7(2):456-462.

Fan D, Mark Hodges D, Zhang J, Kirby CW, Ji X, Locke SJ, Critchley AT, Prithiviraj B (2011). Commercial extract of the brown seaweed Ascophyllum nodosum enhances phenolic antioxidant content of spinach (Spinacia oleracea L.) which protects Caenorhabditis elegans against oxidative and thermal stress. Food Chemistry 124:195-202.

Han YY, Li YB, Fan SX, Liu CJ, Hao JH, Chen QJ, Dong J (2016). Screening and identification of lettuce germplasm for tolerance to high and low temperature. Acta Horticulturae 1127:381-388.

Holm G (1954). Chlorophyll mutations in barley. Acta Agriculturae Scandinavica 4:457-471.

Hoque MM, Ajwa H, Othman M, Smith R, Cahn M (2010). Yield and postharvest quality of lettuce in response to nitrogen, phosphorus, and potassium fertilizers. HortScience 45(10):1539-1544.

Jarak M,Zdravković M, Đuric S, Damjanović M (2006). Response of beans to inoculation and fertilizers. Annals of the Faculty Engineering Hunedoara 4(3):61-66.
Jiménez DJ, Montana JS, Martinez MM (2011). Characterization of free nitrogen fixing bacteria of the genus Azotobacter in organic vegetablegrown Colombian soils. Brazilian Journal of Microbiology 42(3):846858.

Lee RB (1988). Phosphate influx and extracellular phosphatase activity in barley roots and rose cells. New Phytologist 109(2):141-148.

Liu X, Ardo S, Bunning M, Parry J, Zhou K, Stushnoff C, ... Kendal P (2007). Total phenolic content and DPPH radical scavenging activity of lettuce (Lactuca sativa L.) grown in Colorado. LWT - Food Science and Technology 40(3):552-557.

Marketsandmarkets.com (2014). Biostimulants market by active ingredient (acid-based and extract based), by application type (foliar, soil, and seed), by crop type (row crops, fruits and vegetables, and turfand ornamentals) and by region - global trends and forecasts to 2019. USA MarketsandMarkets $^{\mathrm{rm}}$ INC. Retrieved 2016 Jan 11 from http://www.marketsandmarkets.com.

Mou B, RyderEJ (2004). Relationship between the nutritional value and the head structure of lettuce. Acta Horticulturae 637:361-367.

Mou B (2005). Genetic variation of beta-carotene and lutein contents in lettuce. Journal of the American Society for Horticultural Science 130(6):870-876.

Muymas P, Pichyangkura R, Wiriyakitnateekul W, Wangsomboondee T, Chadchawan S, Seraypheap K (2015). Effects of chitin-rich residues on growth and postharvest quality of lettuce. Biological Agriculture and Horticulture 31(2):108-117.

Noaman NH, Fattah A, Khaleafa M, Zaky SH (2004). Factors affecting antimicrobial activity of Synechococcus leopoliensis. Microbiological Research 159(4):395-402.

Or D, Phutane S, Dechesne A (2007). Extracellular polymeric substances affecting pore-scale hydrologic conditions for bacterial activity in unsaturated Soils. Vadose Zone Journal 6(2):298-305.

Pfeiffer W (1996). Auxin induces exocytosis of acid phosphatase in coleoptiles from Zeamays. Physiologia Plantarum 98(4):773-779.

Redmile-Gordon MA, Evershed RP, Hirsch PR, White RP, Goulding KWT (2015).Soil organic matter and the extracellular microbial matrix show contrasting responses to $\mathrm{C}$ and $\mathrm{N}$ availability. Soil Biology and Biochemistry 88:257-267.

Remminghorst U, Rehm B (2006). Bacterial alginates: From biosynthesis to applications. Biotechnology Letters 28(21):1701-1712.

Reyes LF, Villarreal JE, Cisneros-Zevallos L (2007). The increase in antioxidant capacity after wounding depends on the type of fruit or vegetable tissue. Food Chemistry 101(3):12541262.

Rouphael Y, Cardarelli M, Bonini P, Colla G (2017). Synergistic action of a microbial-based biostimulant and a plant derived-protein hydrolysate enhances lettuce tolerance to alkalinity and salinity. Frontiers in Plant Science 8:131.

Saini RK, Shang XM, Ko EY, Choi JH, Keum YS (2016). Stability of carotenoids and tocopherols in ready-to-eat baby-leaf lettuce and salad rocket during low-temperature storage. International Journal of Food Sciences and Nutrition 67(5):489-495.

Skovgaard M, Renjel Encinas S, Jensen OC, Andersen JH, Condarco G,Jørs E (2017). Pesticide residues in commercial lettuce, onion, and potato samples from Bolivia-A threat to public health? Environmental Health Insights 11:1-8. 
Steenhoudt O, Vanderleyden J (2000). Azospirillum, a free-living nitrogenfixing bacterium closely associated with grasses: genetic, biochemical and ecological aspects. FEMS Microbiology Reviews 24(4):487-506.

TakahashiH (2013). Auxin biology in roots. Plant Root 7:49-64.

Tarakhovskaya ER, Maslov YI, Shishova MF (2007). Phytohormones in algae. Russian Journal of Plant Physiology 54 (2):163-170.

Thorp K, Chu Q, Liu J, Bali K, Thorp KR (2016). Automated thinning increases uniformity of in-row spacing and plant size in Romaine lettuce. HortTechnology 26(1):12-19.

Tsavkelova EA, Klimova SY, Cherdyntseva TA, Netrusov AI (2006). Microbial producers of plant growth stimulators and their practical use: A review. Applied Biochemistry and Microbiology 42(2):117-126.
UNECE Standard FFV-22 (2012). Concerning the marketing and commercial quality control of lettuces, curled-leaved endives and broadleaved(Batavian) endives. New York and Geneva: United Nations.

Von Bennewitz E, Hlušek J (2006). Effect of the application of two biopreparations on the nutritional status, vegetative and generative behaviour of 'Jonagold' apple trees. Acta Horticulturae 721:129-135.

Watanabe K, Takihana N, Aoyagi H, HanadaS, Watanabe Y, Ohmura N, Saiki H, Tanaka H (2005). Symbiotic association in Chlorella culture. FEMS Microbiology Ecology 51(2):187-196.

Yin TT, Pin UL, Ghazali AHA (2015). Influence of external nitrogen on nitrogenase enzyme activity and auxin production in Herbaspirillum seropedicae (Z78). Tropical LifeSciences Research 26(1):101-110. 